\title{
PENGEMBANGAN BAHAN AJAR STRUKTUR ALJABAR BERBASIS WEBSITE
}

\section{Fadli}

\begin{abstract}
This research was conducted to produce a web based learning materials which is used in algebra structure course. The respondents of this research were student teachers of $6^{\text {th }}$ semester, majoring in Maths, Faculty of Educational and Teaching Program, University of PGRI Palembang. The learning materials were developed by IDI (Instructional Development Institute) model. To measure of its validity, practicality, and effectiveness, a formative evaluation and a field test were used. The results showed that the $4^{\text {th }}$ prototype of the learning materials is potentially effective that $67,57 \%$ of students are motivated, 56,76\% of students are interested and the students' result of study which reached the point of 54,05\%, are considered excellent. It can be concluded that the learning materials of structure of algebra based on website is valid and practical on study of structure of algebra, and has a potential effect.
\end{abstract}

Keyword: development, learning material, website, structure of algebra

\begin{abstract}
Abstrak
Penelitian ini dilakukan untuk menghasilkan bahan ajar yang berbasis web yang dapat dipergunakan dalam mata kuliah struktur aljabar. Responden penelitian ini adalah mahasiswa calon guru semester keenam dengan konsentrasi bidang matematika di fakultas ilmu keguruan dan ilmu pendidikan, Universitas PGRI Palembang. Bahan ajar dikembangkan dengan menggunakan model IDI (Instructional Development Institute). Untuk mengukur validitas, keterpakaian dan efektivitasnya dilakukan evaluasi formatif dan tes lapangan. Hasilnya menunjukkan bahwa prototipe keempat bahan belajar sungguh efektif sehingga 67,57\% dari mahasiswa termotivasi, 56,76\% mahasiswa tertarik, dan hasil belajar siswa yang mencapai 54,05\% dianggap sangat memuaskan. Dengan demikian disimpulkan bahwa bahan belajar untuk struktur aljabar berbasis website adalah valid dan dapat dipergunakan untuk belajar struktur aljabar serta mempunyai efek yang tangguh.
\end{abstract}

Kata kunci: pengembangan, bahan belajar, website, struktur aljabar.

\section{PENDAHULUAN}

Struktur aljabar menurut Wahyudin (1989) adalah ilmu yang mempelajari suatu himpunan dengan satu atau lebih operasi biner yang diberla-kukan pada sistem aljabar tersebut. Misalkan S adalah suatu himpunan yang dilengkapi dengan sekelompok operasi biner o dan \#, maka $S$ menjadi satu struktur aljabar dengan satu operasi biner yang dinotasikan dengan $(S, 0)$ atau $(S, \#)$, atau dua operasi biner yang dinotasikan $(S, o, \#)$ atau $S, \#, o)$.

Tujuan kurikuler dalam mata kuliah Struktur Aljabar berdasarkan silabus Program Studi Pendidi-kan Matematika Fakultas Keguruan dan Ilmu Pendidi-kan (FKIP) Universitas Persatuan Guru Republik Indo-nesia (PGRI) Palembang adalah agar diharapkan mahasiswa memahami lebih dalam tentang Struktur Aljabar dan dapat menerapkannya dalam menyelesai-kan masalah aljabar sederhana, serta mampu berpikir logis dan bernalar secara matematis dalam menyelesai-kan suatu masalah. Tujuan kurikuler mata kuliah Struktur Aljabar dalam tiga tahun terakhir ini dapat dikatakan belum tercapai, karena berdasarkan Daftar Nilai Akademik mahasiswa Program Studi Pendidikan Matematika FKIP Universitas PGRI Palembang, masih banyak mahasiswa yang mendapat nilai kurang dari 70 (kategori: C). Hal ini dapat dilihat dari rekap nilai tiga tahun terakhir.

Tabel 1. Rekap Nilai Mata Kuliah Struktur Aljabar Tiga Tahun Terakhir

\begin{tabular}{|c|c|c|c|c|c|c|c|c|c|c|}
\hline \multirow{2}{*}{ 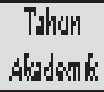 } & \multicolumn{10}{|c|}{ 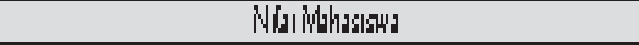 } \\
\hline & A & $t$ & 8 & $t$ & 6 & $t$ & $\bar{\Xi}$ & $t$ & T & t \\
\hline 100120 & III & 101.15 & 100 & 5076 & 8 & dif & 1 & 091 & 1 & 051 \\
\hline 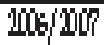 & 21 & $10 \%$ & W & 41 4 & Di & 47,11 & - & - & - & $=$ \\
\hline 20606 & III & 9 & 10 & 90 & 6 & 195 & 5 & 217 & - & - \\
\hline
\end{tabular}


Teknologi pendidikan merupakan suatu bidang yang mencakup penerapan proses yang kompleks dan terpadu dalam menganalisis dan memecahkan masalah-masalah pembelajaran (Miarso, 2007). Hal ini berarti, dalam setiap pemecahan masalah melibatkan orang, prosedur, ide, peralatan, dan organisasi. Dalam teknologi pendidikan, pemecahan masalah itu terjelma dalam bentuk semua sumber belajar yang didesain dan atau dipilih dan atau digunakan dalam keperluan belajar. Salah satu sumber belajar ini dapat diidentifi-kasi sebagai media pembelajaran. Media pembelajaran yang dimaksudkan tentu media pembelajaran yang sesuai atau efektif untuk membantu keperluan pembe-lajaran dalam mata kuliah Struktur Aljabar.

Teknologi komputer adalah sebuah penemuan yang memungkinkan menghadirkan media pembelaja-ran yang lebih optimal. Teknologi berbasis komputer merupakan cara-cara memproduksi dan menyampai-kan bahan dengan menggunakan perangkat yang bersumber pada mikroprosesor (Seels, 1994). Tekno-logi berbasis komputer ini dibedakan dari teknologi lain karena menyimpan informasi secara elektronik dalam bentuk digital, baik sebagai bahan cetak atau visual.

Saat pertama-tama komputer mulai diperkenal-kan khususnya pada pembelajaran, maka komputer menjadi dikenal atau populer di kalangan anak didik. Bisa dimengerti karena berbagai variasi teknik meng-ajar bisa dibuat dengan bantuan komputer tersebut. Setelah itu, teknologi pembelajaran terus berkembang. Namun pada prinsipnya teknologi tersebut dapat dikelompokkan menjadi dua, yaitu technology based learning dan technology based web-learning.

Banyak website tentang media pembelajaran, tetapi tidak mengakomodir minat mahasiswa dalam pembelajaran. Karena website yang dibuat hanya sebagai informasi saja, bukan sebagai bahan ajar dan latihan bagi mahasiswa. Media pembelajaran yang baik harus memenuhi beberapa syarat. Media pembe-lajaran harus meningkatkan motivasi mahasiswa. Selain itu, media pembelajaran juga harus merangsang mahasiswa mengingat apa yang sudah dipelajari selain memberikan rangsangan belajar baru. Media pembelajaran yang baik juga akan mengaktifkan mahasiswa dalam memberikan tanggapan, umpan balik, dan juga mendorong mahasiswa untuk melakukan praktik-praktik dengan benar.

Peneliti bermaksud merancang website yang merupakan media pembelajaran untuk mata kuliah Struktur Aljabar sebagai pengembangan bahan ajar yang berbasis website yang diharapkan dapat mening-katkan hasil belajar mahasiswa dalam pembela- jaran Struktur Aljabar, yang sesuai dengan kriteria Dikmenum tahun 2006 (Wahono, 2006) untuk menilai karya media pembelajaran yang masuk pada program Smart Teacher. Adapun aspek-aspek tersebut adalah aspek rekayasa perangkat lunak, aspek desain pembelajaran, dan aspek komunikasi visual.

Selain pembuatan media pembelajaran berupa bahan ajar Struktur Aljabar berbasis website, peneliti ingin tahu efek dari pembelajaran Struktur Aljabar yang menggunakan bahan ajar yang berbasis website. Peneliti bermaksud menguji coba efek dari pembelaja-ran Struktur Aljabar yang menggunakan bahan ajar berbasis website terhadap pembelajaran Struktur Aljabar di Program Studi Pendidikan Matematika FKIP Universitas PGRI Palembang, serta respon mahasiswa terhadap bahan ajar Struktur Aljabar berbasis website cukup baik atau tidak.

Oleh karena itu, tujuan dalam penelitian ini adalah menghasilkan deskripsi proses pengembang-an prototype bahan ajar Struktur Aljabar berbasis website yang dikembangkan valid dan praktis dan mengetahui efek bahan ajar Struktur Aljabar berbasis website terhadap motivasi, sikap, dan hasil belajar mahasiswa selama pembelajaran pada mata kuliah Struktur Aljabar.

\section{KAJIAN PUSTAKA}

\section{Hakikat E-learning}

Electronic learning disingkat menjadi e-learning. Kata ini terdiri dari dua bagian, yaitu ' $e$ ' yang merupa-kan singkatan dari 'electronica' dan 'learning' yang berarti 'pembelajaran'. Jadi e-learning berarti pembela-jaran dengan menggunakan jasa bantuan perangkat elektronika. Jadi, dalam pelaksanaannya e-learning menggunakan jasa audio, video atau perangkat komputer atau kombinasi dari ketiganya. Dengan kata lain, e-learning adalah pembelajaran yang pelaksanaan-nya didukung oleh jasa teknologi seperti telepon, audio, videotape, transmisi satelit atau komputer. E-learning memang merupakan suatu teknologi pembe-lajaran yang relatif baru di Indonesia.

E-learning berarti pembelajaran dengan menggu-nakan jasa bantuan perangkat elektronika. Jadi dalam pelaksanaannya e-learning menggunakan jasa audio, video atau perangkat komputer atau kombinasi dari ketiganya. Dengan kata lain, e-learning adalah pembela-jaran yang pelaksanaannya didukung oleh jasa teknologi seperti telepon, audio, videotape, transmisi satelit atau komputer.

Website adalah situs yang dapat diakses dan dil- 
ihat oleh para pengguna internet. Pembelajaran berbasis website merupakan salah satu media pembelajaran yang menggunakan e-learning, karena menggunakan elektronika.

\section{Teknologi Pendukung E-learning}

Dalam praktiknya, e-learning memerlukan bantuan teknologi. Dalam perkembangannya, kompu-ter yang paling populer dipakai sebagai alat bantu pembelajaran secara electronik, karena itu dikenal dengan istilah.

a. Computer Based Learning (CBL) yaitu pembelajaran yang sepenuhnya menggunakan komputer.

b. Computer Assisted Learning (CAL) yaitu pembelaja-ran yang menggunakan alat bantu utama komputer.

Saat pertama-tama komputer mulai diperkenal-kan khususnya pada pembelajaran, maka komputer menjadi dikenal atau populer di kalangan anak didik. Bisa dimengerti karena berbagai variasi teknik meng-ajar bisa dibuat dengan bantuan komputer tersebut. Setelah itu, teknologi pembelajaran terus berkembang. Namun, pada prinsipnya teknologi tersebut dapat dikelompokkan menjadi dua, yaitu.

a. Technology based learning, pada prinsipnya terdiri dari Audio Information Technologies (misalnya radio, audio tape, voice mail telephone) dan Video Information Technologies (misalnya video tape, video text, video messaging).

b. Technology based web-learning, pada dasarnya adalah data information technologies (misalnya bulletin board, internet, e-mail, tele-collaboration).

Dalam pelaksanaan pembelajaran sehari-hari, yang sering dijumpai adalah kombinasi dari kedua teknologi tersebut (audio/data, video/data, audio/video). Teknologi ini juga sering di pakai pada pendidikan jarak jauh (distance education), dimaksudkan agar komunikasi antara murid dan pendidik bisa terjadi dengan keunggulan teknologi e-learning ini.

Pemanfaatan Website sebagai Media Pembelajaran

Ahli-ahli pendidikan dan internet menyarankan beberapa hal yang perlu diperhatikan sebelum seseorang memilih website sebagai media dalam pembelajaran (Hartanto dan Purbo, 2002) antara lain.

a. Analisis Kebutuhan (Need Analysis). Dalam tahapan awal, satu hal yang perlu dipertimbangkan adalah apakah memang memerlukan e-learning. Pertanya-an ini tidak dapat dijawab dengan perkiraan atau dijawab berdasarkan atas saran orang lain. Setiap lembaga menentukan teknologi pembelajaran sendiri yang berbeda satu sama lain. Untuk itu perlu diadakan analisis kebutuhan atau need analysis yang mencakup studi kelayakan baik secara teknis, ekonomis, maupun sosial.

b. Rancangan Instruksional yang berisi tentang isi pelajaran, topik, satuan kredit, dan bahan ajar/ kurikulum.

c. Evaluasi yaitu sebelum program dimulai, ada baiknya dicobakan dengan mengambil beberapa sampel orang yang dimintai tolong untuk ikut mengevaluasi.

Terakhir yang harus diperhatikan masalah yang sering dihadapi yaitu.

a. Masalah akses untuk bisa melaksanakan website seperti ketersediaan jaringan internet, listrik, telepon, dan infrastruktur yang lain.

b. Masalah ketersediaan software (piranti lunak). Bagaimana mengusahakan piranti lunak yang tidak mahal.

c. Masalah dampaknya terhadap kurikulum yang ada.

d. Masalah skill and knowledge.

\section{METODOLOGI PENELITIAN}

\section{Jenis dan Model Penelitian}

Jenis penelitian ini menggunakan metode riset pengembangan atau development research (Akker, 1999). Penelitian ini akan mengembangkan bahan ajar berbasis website pada mata kuliah Struktur Aljabar. Seels (1994) mengemukakan bahwa pengembangan adalah proses penerjemahan spesifikasi desain ke dalam bentuk fisik.

Model pengembangan bahan ajar Struktur Aljabar berbasis website oleh peneliti dalam penelitian ini adalah menggunakan model Instructional Development Institute (IDI). IDI menerapkan prinsip-prinsip pendekatan sistem. Ada tiga tahapan besar pendekatan sistem, yaitu penemuan (define) atau analisis kebutuhan, pengembangan (develop), dan evaluasi (evaluate). Ketiga tahapan tersebut dihubung-kan dengan umpan balik (feedback) untuk mengadakan revisi (Syukur, 2008).

\section{Prosedur Penelitian}

Secara umum, rancangan penelitian dapat dilihat dari bagan berikut:

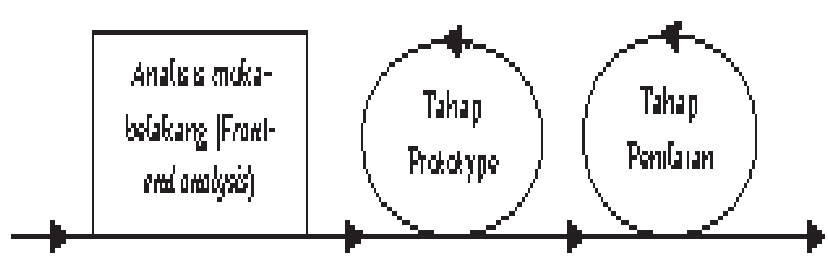

Gambar 1. Rancangan Penelitian (Fauzan, 2002) 
Rancangan penelitian dapat diuraikan pada tahap prosedur berikut ini.

a. Tahap Analisis Muka-Belakang (Front-End Analysis)

Tahap analisis muka-belakang dilakukan untuk mendapatkan gambaran kondisi di lapangan. Pada tahap ini dilakukan langkah-langkah yaitu melakukan wawancara dengan teman sejawat, menganalisis silabus mata kuliah Struktur Aljabar, menganalisis dan mereview buku referensi Struktur Aljabar, serta mem-pelajari karakteristik mahasiswa

\section{b. Tahap Prototype}

Hasil dari analisis muka-belakang digunakan untuk merancang prototype bahan ajar struktur aljabar berbasis website. Pembuatan prototype ini dilakukan melalui dua tahap, yaitu tahap validasi dan praktika-litas.

c. Tahap Penilaian (Assesment)

Pada tahap penilaian, kegiatan dipusatkan untuk mengevaluasi apakah prototype (versi ujicoba) dapat digunakan sesuai dengan harapan dan efektif untuk meningkatkan kualitas dan hasil belajar maha-siswa. Aspek efektivitas yang diamati dalam proses perkuliahan yang menggunakan bahan ajar Struktur Aljabar berbasis website di kelas uji coba adalah aktivi-tas mahasiswa.

\section{Teknik Pengumpulan Data}

Untuk mendapatkan data yang diperlukan dalam penelitian ini digunakan teknik pengumpulan data berupa angket, observasi, dan tes hasil belajar terhadap respon mahasiswa pada media pembelajaran berupa bahan ajar Struktur Aljabar berbasis website.

a. Angket, digunakan untuk mengukur sikap maha-siswa dan tingkat motivasi mahasiswa terhadap pembelajaran struktur aljabar berbasis website.

b. Observasi, digunakan untuk melihat motivasi mahasiswa selama pembelajaran menggunakan bahan ajar Struktur Aljabar berbasis website. Obser-vasi terhadap subjek penelitian dilakukan selama proses pembelajaran.

c. Tes Hasil Belajar, digunakan untuk mengukur hasil belajar mahasiswa terhadap mata kuliah Struktur Aljabar setelah pembelajaran mengguna-kan bahan ajar Struktur Aljabar berbasis website.

\section{HASIL DAN PEMBAHASAN}

\section{Hasil Tahap Analisis Muka-Belakang (Front-End Analysis)}

Perangkat pembelajaran bahan ajar Struktur Aljabar dirancang berdasarkan analisis muka bela-kang.
Kegiatan ini dimulai dari melakukan wawancara dengan teman sejawat, menganalisis silabus mata kuliah Struktur Aljabar, menganalisis buku referensi Struktur Aljabar, mereview literatur tentang bahan ajar Struktur Aljabar, serta mempelajari karakteristik maha-siswa.

Berikut ini diuraikan hasil analisis muka belakang sebagai berikut.

a. Melakukan wawancara dengan teman sejawat

Wawancara dengan teman sejawat (dosen pengampu mata kuliah Struktur Aljabar) bertujuan untuk mengetahui masalah/hambatan/fenomena apa saja yang dihadapi di lapangan sehubungan dengan perkuliahan Struktur Aljabar.

Dari hasil wawancara dapat disimpulkan bahwa mahasiswa kurang memahami konsep dari mata kuliah tersebut, karena bersifat abstrak. Selain itu, mahasiswa kurang termotivasi untuk mencari bahan referensi mengenai materi yang diberikan.

b. Menganalisis silabus mata kuliah Struktur Aljabar

Berdasarkan analisis silabus mata kuliah Struktur Aljabar yang ada pada Program Studi Pendi-dikan Matematika FKIP Universitas PGRI Palembang, materi yang diajarkan terlalu padat tetapi kurang men-dalam dan kompetensi yang diharapkan belum jelas.

Selain itu, kegiatan perkuliahan yang ada masih bersifat teacher centered. Proses perkuliahan yang dirancang hendaknya melibatkan mahasiswa secara aktif dan mandiri. Dengan cara memberikan bahan ajar Struktur Aljabar berbasis website kepada maha-siswa. c. Menganalisis dan mereview buku referensi Struktur Aljabar

Analisis buku referensi Struktur Aljabar bertuju-an untuk melihat isi materi khususnya materi Dasar-dasar Grup, Subgrup, dan Order dari Grup. Bagaimana cara materi disajikan, contoh ataupun yang bukan contoh dalam latihan soal dan tugas-tugas yang sesuai dengan silabus mata kuliah yang ada. Setelah buku referensi Struktur Aljabar dianalisis, kemudian direview menjadi bahan ajar sesuai dengan silabus yang telah dikembangkan.

d. Mempelajari karakteristik mahasiswa

Karakteristik mahasiswa perlu menjadi dasar dalam pengembangan bahan ajar Struktur Aljabar berbasis website. Tujuan peneliti mempelajari karakte-ristik mahasiswa adalah untuk mengetahui kemam-puan umum mahasiswa tentang struktur aljabar, kemampuan matematika mahasiswa secara umum.

Hal ini dilakukan selain untuk menentukan subjek uji coba penggunaan bahan ajar Struktur Aljabar berbasis website juga untuk sebagai acuan dalam mengembangkan alat tes/tingkat kesulitan soal serta

Perspektif Ilmu Pendidikan - Vol.23 Th. XIV April 2011 
penggunaan bahasa dalam pengembangan bahan ajar Struktur Aljabar berbasis website.

\section{Hasil Tahap Prototipe (Prototype)}

Hasil dari analisis muka-belakang digunakan untuk merancang prototype bahan ajar Struktur Aljabar berbasis website. Pembuatan prototype dalam penelitian ini dilakukan melalui dua tahap, yaitu Tahap Validasi dan Praktikalitas.

a. Tahap Validasi

Pada tahap ini terbagi dalam empat prototype, yaitu prototype I, prototype II, prototype III, dan prototype IV.

\section{(1) Prototype I}

Pada tahap ini dirancang bahan ajar Struktur Aljabar berupa materi Sifat-sifat Grup, Subgrup dan Order dari Grup. Bahan ajar yang dibuat berupa materi, contoh ataupun bukan soal, latihan, tugas, dan evaluasi. Bahan ajar dibuat dengan paper-based berupa naskah materi untuk mempermudah validasi pada tahap awal. Berikut ini adalah hasil bahan ajar struktur aljabar yang dibuat dengan menggunakan paper-based.

Berdasarkan hasil uji validitas, maka dapat disimpulkan bahwa bahan ajar Struktur Aljabar berupa paper-based yang peneliti desain untuk materi website masih ada kekurangan yang menurut para ahli akan mengakibatkan mahasiswa kurang memahami materi yang disampaikan. Kekurangan-kekurangan pada prototype I ini akan menjadi acuan bagi peneliti untuk memperbaikinya.

Selanjutnya dari perbaikan bahan ajar Struktur Aljabar berbasis paper-based, dilanjutkan dengan men-sketsa bahan ajar Struktur Aljabar pada kertas yang bertujuan untuk memperoleh gambaran tentang objek dan apa saja yang akan ditampilkan pada website.

(2) Prototype II

Tahap ini berupa perancangan materi dari $p a-$ per-based (Prototype I) ke komputer (website). Software yang digunakan dalam merancangnya menggunakan PHP + MySql dan Macromedia Flash 8.0 yang selanjut-nya diedit menggunakan Macromedia Dreamweaver 8.0.

Dalam merancang materi Dasar-dasar Grup serta Subgrup dan Order Grup untuk setiap slide pada umumnya sama. Tahap ini, website yang telah dibuat. Karena itu, peneliti menunjukkan sebagian dalam merancangnya. Berikut hasil prototype II (website).

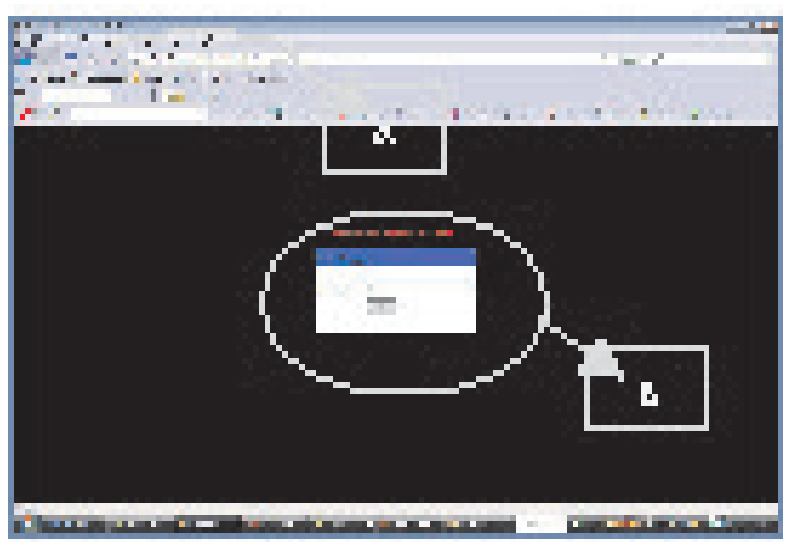

Keterangart

A. Alamat website yaitu http:/tes isku uuug.com

B. Sebelum masuk ke menu utama, user terlebih dahulu bgin dens an nama mereka

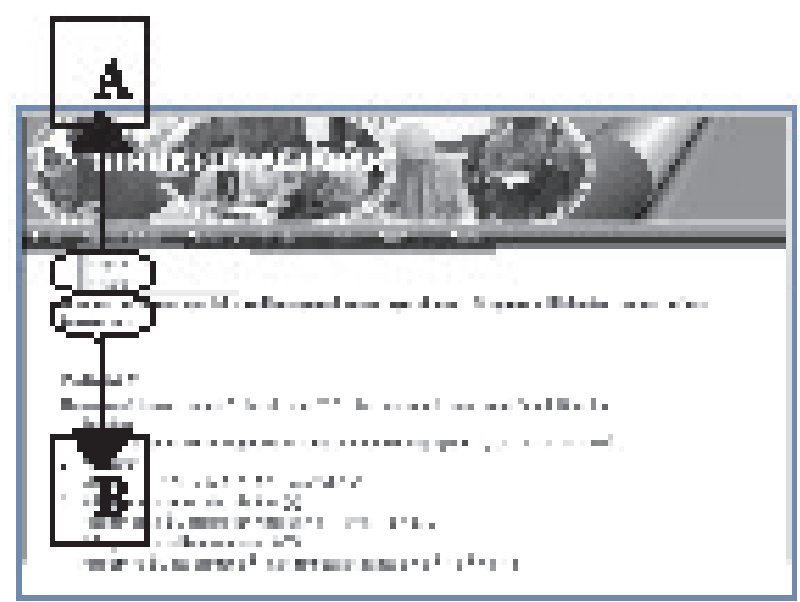

\section{Keterangarr}

A. Belajar 1: berisikan materi mengenai $D$ as ar-d as ar Grup, dilengkapi dengan conto h so al, latihan, tug as an ev aluasi

B. Belajar 2: berisikan materi mengenai Subgrup d an Ord er dariGrup, dilengkapi dengan conto $h$ so al, latihan tugas dan evaluasi

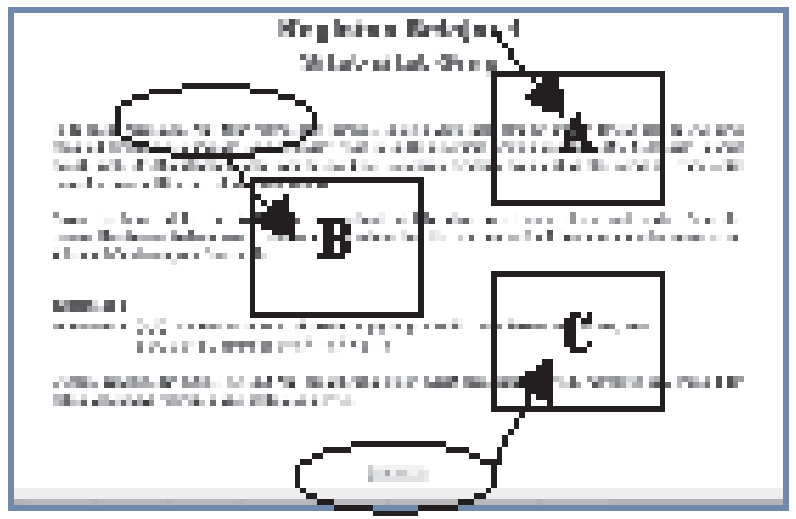

\section{Keterang art}

A. Materi kesiatan belajar 1 tentang sifat-sif at grup

B. Bahan ajar bersifat personal, meryapadengan nama $u s g$ login

C. To mbol untuk melanjutkan ke materi berikutnya 


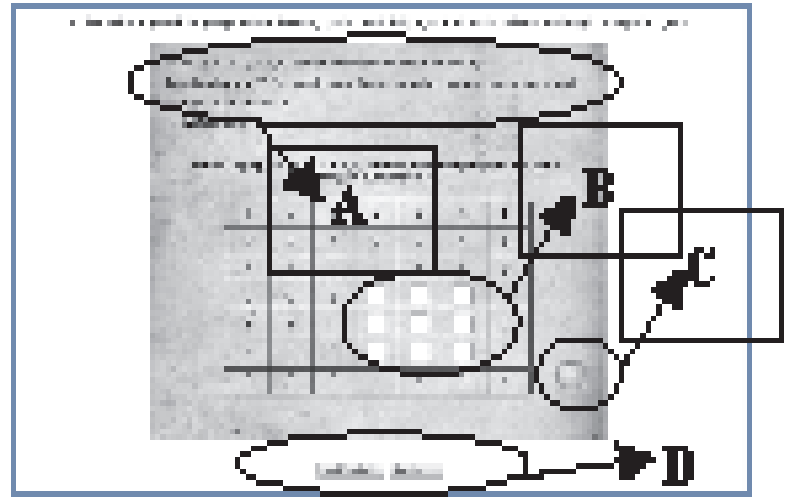

Keterangan:

A. Contoh soal sebagai latihan interaktik

B. Kolom-kolom yang harus diisi

C. Tombol untuk melanjutkan soal berikutnya
D. Tombol untuk kembali/melanjutkan ke materi berikutnya

Setelah bahan ajar Struktur Aljabar berbasis website didesain dalam bentuk prototype II, maka dilakukan uji validitas terhadap pakar (expert review). Uji validitas untuk melihat kekurangan dari prototype II baik dari segi isi materi (content) maupun dari tampilan (layout). Kekurangan-kekurangan pada prototype II ini akan menjadi acuan bagi peneliti untuk memperbaikinya untuk menjadi bahan ajar Struktur Aljabar berbasis website prototype. Berdasarkan saran-saran dari validator pada prototype II, peneliti merevisi prototype II sebagai dasar rancangan prototype III. Berikut perubahan sebelum dan sesudah revisi prototype II :

Tabel 2. Perubahan Sebelum dan Sesudah Revisi Prototype II

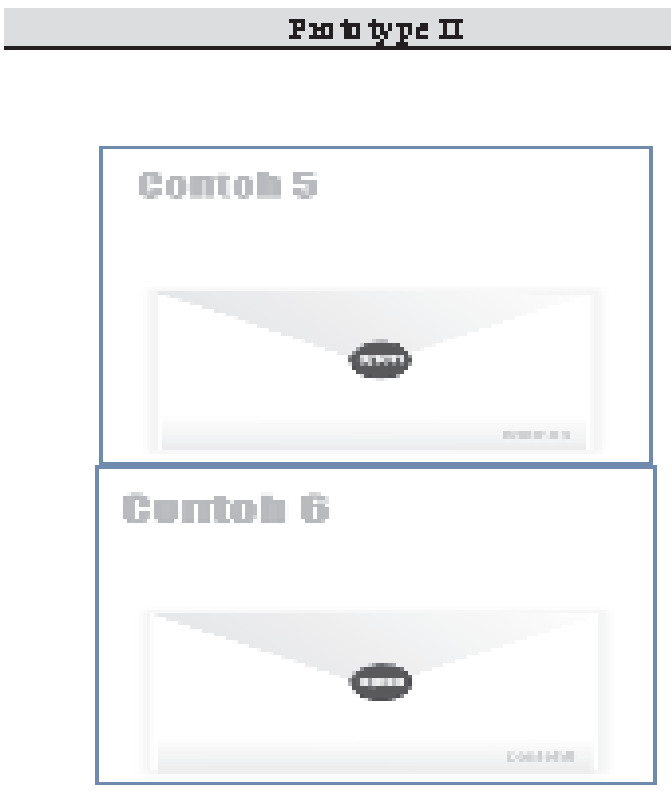

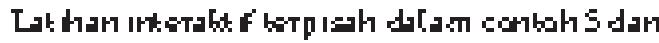
conbahs
Pan ty type III

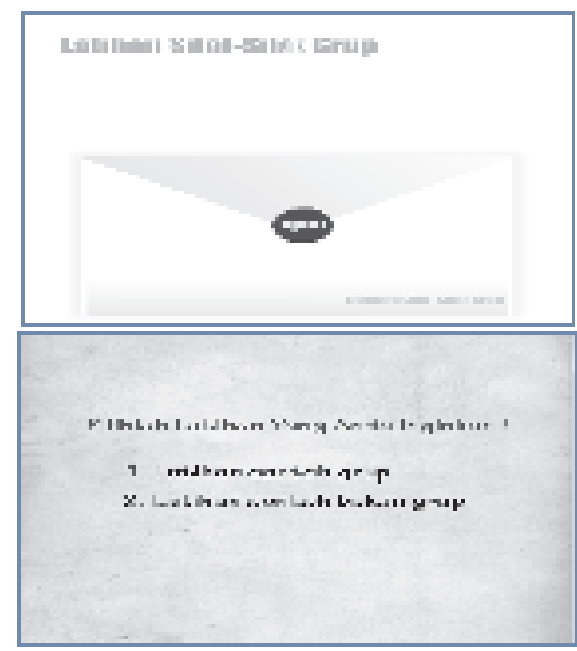

- Corkoh S dan Corkoh G, djad kan [atıtun sıłat-afat Gт

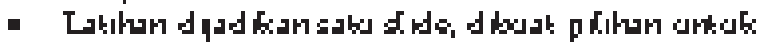
matgor ban [at han

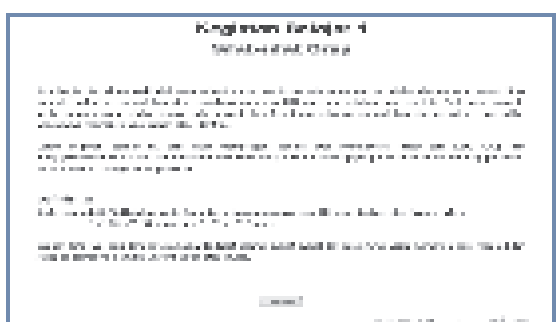

- Relum ada merva sublind arkak ke maborl

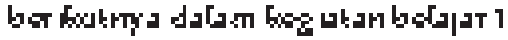

- Simbol matematka bolosm tertaca

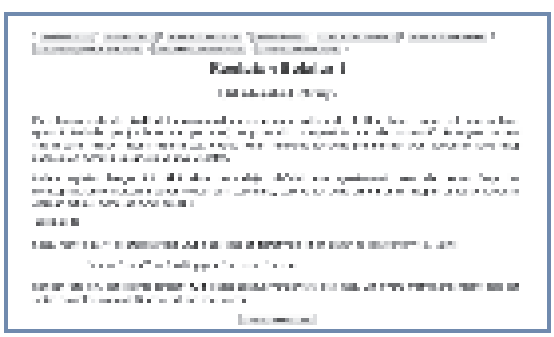

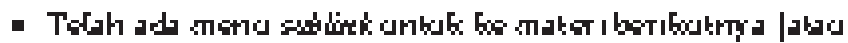

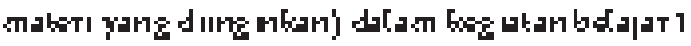

- Tetd ri dat I definisi teoterma, conboh dan lat han soall

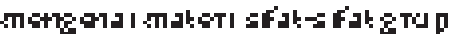

- Tombol [anat, lsbih dipejeras bo maberi yangakan di Ddapat

- Skmbol matomat ka tolah borbaca 


\section{Frahtrall}

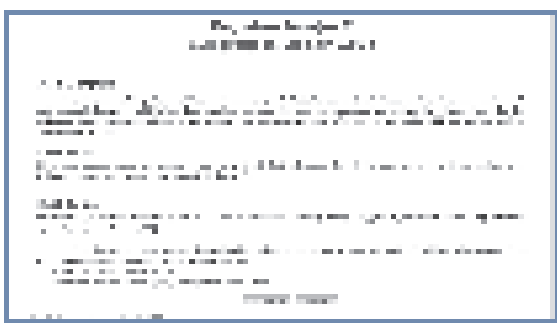

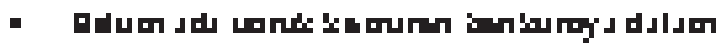

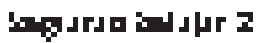

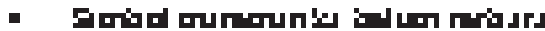

Protarin II I

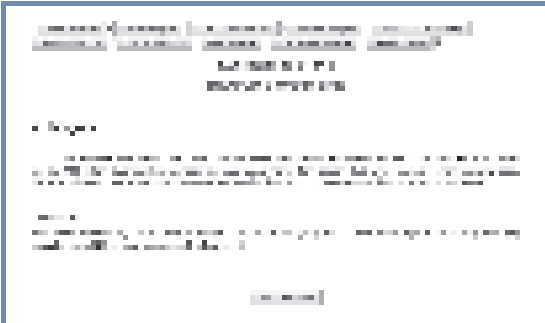

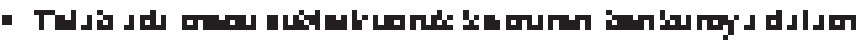

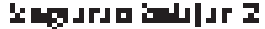

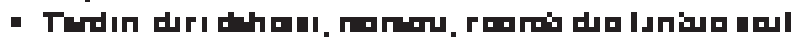

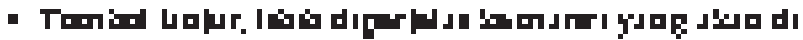

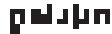

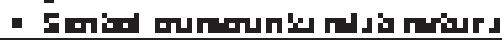

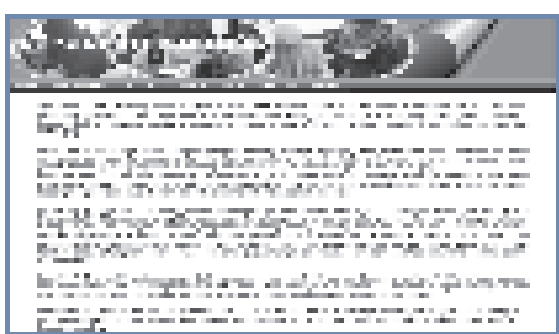

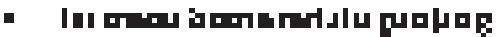

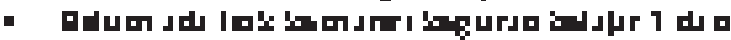

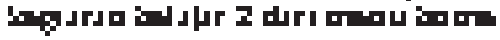

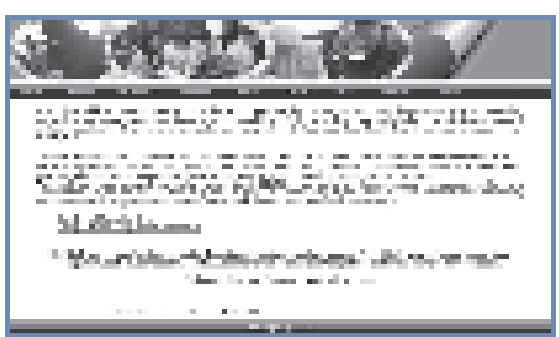

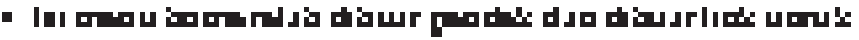

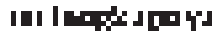

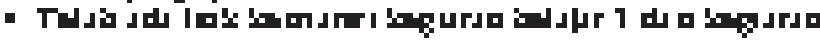

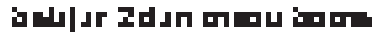

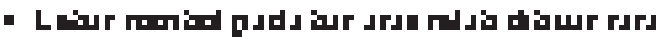

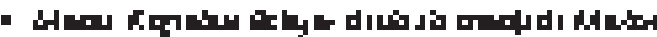

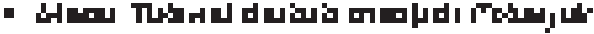

- rangiva

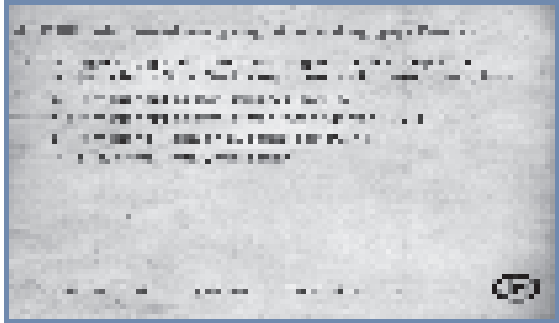

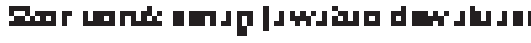
drumarum

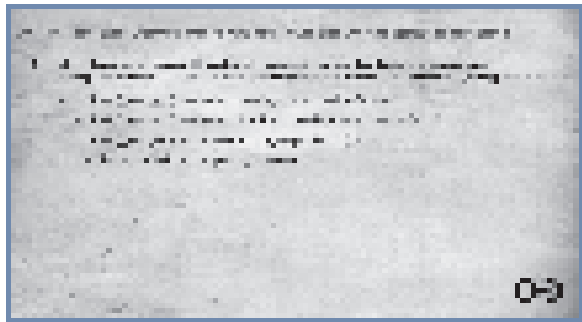

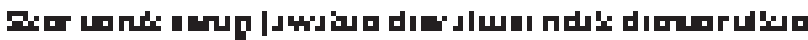

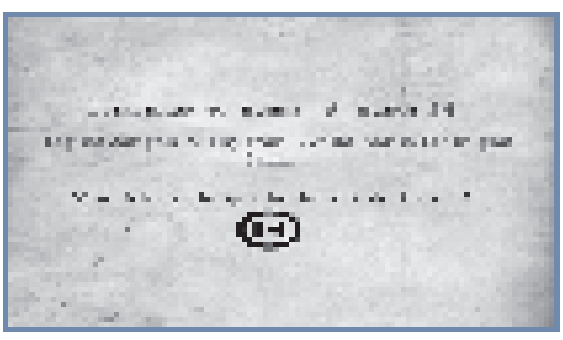

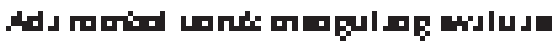

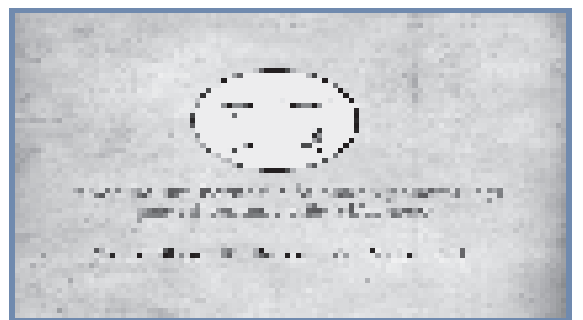

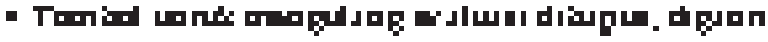

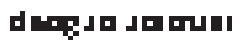




\section{(3) Prototype III \& Prototype IV}

Berdasarkan hasil uji validitas, maka dapat disimpulkan bahwa bahan ajar Struktur Aljabar berbasis website yang peneliti desain telah lebih baik dari prototype II. Kekurangan-kekurangan pada prototype III ini akan menjadi acuan bagi peneliti untuk memperbaikinya agar menjadi bahan ajar Struktur Aljabar berbasis website prototype IV.

Pada prototype III dilakukan juga uji coba yang pertama (kelompok kecil) dalam penelitian ini adalah para mahasiswa semester VI kelas VI.I yang berjumlah lima orang yang diambil secara acak. Hal ini dilakukan untuk melihat keefektifan bahan ajar Struktur Aljabar berbasis website yang digunakan pada saat pembela-jaran. Indikator yang dilihat adalah sikap mahasiswa, tingkat motivasi dalam belajar mandiri, dan hasil belajar. Pembelajaran dilakukan secara mandiri di luar jam kuliah dengan mengkondisikan satu komputer untuk satu orang mahasiswa. Selama pembelajaran, kegiatan mahasiswa diobservasi untuk melihat tingkat motivasi. Untuk melihat apakah mahasiswa telah mencapai tujuan pembelajaran, maka mahasiswa diberikan soal-soal latihan dan tugas di mana dalam mengerjakan latihan dan tugas tersebut mahasiswa menggunakan bahan ajar Struktur Aljabar berbasis website sebagai panduannya. Berdasarkan hasil observasi selama kegiatan pembelajaran diperoleh tingkat motivasi mahasiswa belajar secara mandiri dengan menggunakan bahan ajar Struktur Aljabar rata-rata mempunyai tingkat motivasi dengan kategori termotivasi dan sikap mahasiswa terhadap bahan ajar Struktur Aljabar rata-rata mempunyai sikap dengan kriteria tertarik terhadap bahan ajar Struktur Aljabar berbasis website.

Desain prototype IV dilakukan berdasarkan saran-saran dari validator pada prototype III. Perubahan prototype IV terjadi hanya pada tampilan websitenya saja dan untuk materi pada simbol-simbol matematika yang tidak terbaca. Berikut perubahan sebelum dan sesudah revisi prototype III.

Tabel 3. Perubahan Sebelum dan Sesudah Revisi Prototype III

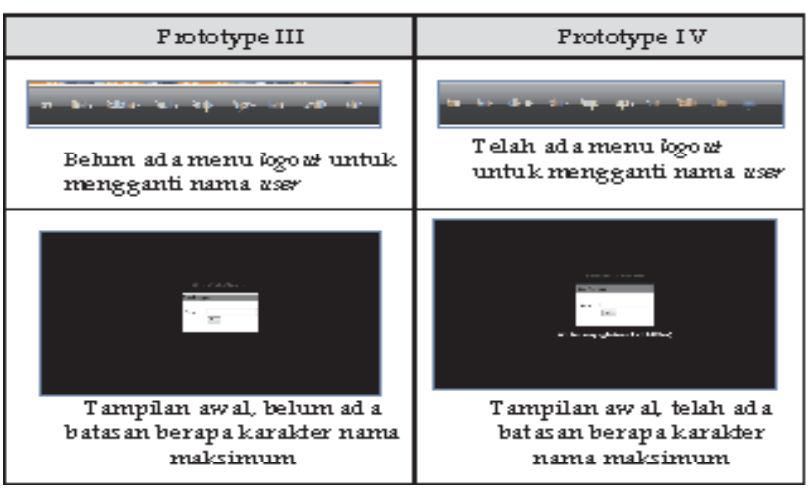

a. Tahap Praktikalitas

Pada tahap uji coba yang kedua merupakan tahap praktikalitas yang dilakukan pada mahasiswa semester VI kelas VI.E dengan jumlah 37 orang. Hal ini dilakukan untuk melihat keefektifan bahan ajar struktur aljabar berbasis website. Indikator yang dilihat adalah tingkat motivasi dalam belajar mandiri, sikap mahasiswa terhadap bahan ajar Struktur Aljabar berbasis website, dan hasil belajar mahasiswa.

b. Hasil Tahap Penilaian (Assessment)

1) Hasil Penilaian Tingkat Motivasi Mahasiswa

Berdasarkan hasil observasi aktivitas maha-siswa selama kegiatan pembelajaran diperoleh tingkat motivasi mahasiswa dalam pembelajaran struktur aljabar berbasis website, yaitu terjadi peningkatan 8,10\% pada kategori Sangat Termotivasi dan 27,03\% pada kategori Termotivasi. Sedangkan kategori Cukup Termotivasi terjadi penurunan sebesar $27,03 \%$, dan kategori Kurang termotivasi turun $8,10 \%$.

Dari hasil observasi per deskriptornya, deskriptor kedua sampai ketujuh terjadi peningkatan persen-tase. Sedangkan deskriptor kedelapan sampai kesepu-luh terjadi penurunan persentase.

Untuk deskriptor tingkat kehadiran mahasiswa tidak terjadi perubahan, deskriptor mengekspresikan perasaan gembira naik $48,65 \%$, deskriptor mempelajari materi dengan tenang naik $27,03 \%$, deskriptor mempe-lajari materi secara sistematis naik $43,243 \%$, deskriptor mencatat atau meng-copy materi naik 29,73\%, deskrip-tor mengerjakan latihan di website tidak terjadi peruba-han, deskriptor berkonsentrasi naik $8,11 \%$, deskriptor bermenung turun $32,43 \%$, deskriptor ber-tanya bila memerlukan turun $21,62 \%$, dan deskriptor membantu teman yang membutuhkan penjelasan turun $21,62 \%$.

Berikut diagram garis hasil observasi motivasi mahasiswa $(\mathrm{n}=37)$ untuk tiap deskriptor :

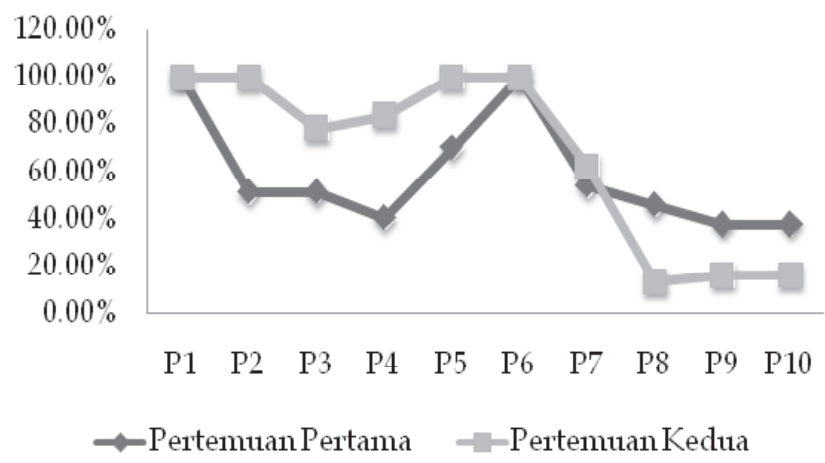

Gambar 2. Diagram Garis Hasil Observasi TingkatMotivasi Mahasiswa untuk Tiap Diskriptor

Keterangan:

P1 : Kehadiran mahasiswa

Perspektif Ilmu Pendidikan - Vol.23 Th. XIV April 2011 
P2 : Mengekspresikan perasaan gembira

P3 : Mempelajari materi dengan tenang

P4 : Mempelajari materi secara sistematis

P5 : Mencatat atau meng-copy materi

P6 : Mahasiswa mengerjakan latihan di website

P7 : Mahasiswa berkosentrasi

P8 : Mahasiswa bermenung

P9 : Bertanya bila memerlukan

P10 : Membantu teman yang membutuhkan

Berdasarkan hasil angket mengenai tingkat motivasi mahasiswa terhadap pembelajaran struktur aljabar berbasis website yang diberikan pada akhir pertemuan terdapat 27,03\% siswa termasuk dalam kriteria Sangat Termotivasi, 67,57\% termasuk dalam kriteria Termotivasi, dan 5,41\% termasuk dalam kriteria Cukup Termotivasi.

2) Hasil Penilaian Sikap Mahasiswa

Berdasarkan hasil angket mengenai sikap maha-siswa semester VI kelas VI.E terhadap pembelajaran struktur aljabar berbasis website yang diberikan pada akhir pertemuan terdapat 18,92\% mahasiswa termasuk dalam kriteria Sangat Tertarik; 56,76\% termasuk dalam kriteria Tertarik; 21,62\% termasuk dalam kriteria Cu-kup Tertarik; dan sisanya 2,7\% termasuk dalam kriteria Kurang Tertarik. Berikut ini diagram batang hasil angket sikap mahasiswa.

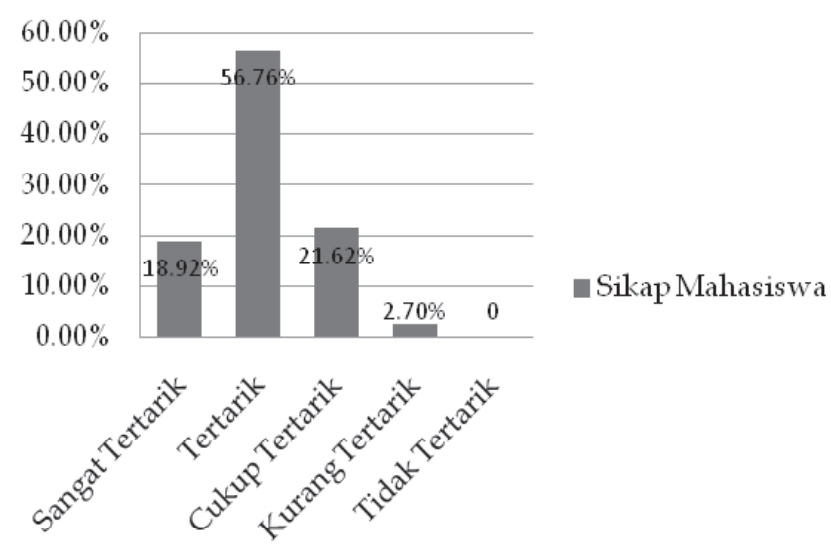

Gambar 3. Diagram Batang Hasil Angket Sikap Mahasiswa

3) Hasil Penilaian Hasil Belajar Mahasiswa

Evaluasi diberikan dalam dua tahap, masing-masing 30 menit, dan skor maksimum bila benar semua adalah 40. Tahap pertama mengenai materi sifat-sifat grup, dan tahap kedua mengenai materi subgroup dan order grup. Jadi total skor maksimum bernilai benar adalah 80 , yang nantinya akan dikon-versi pada interval 0 - 100 .

Hasil dari evaluasi ini ditambahkan dengan nilai tugas dan latihan, menghasilkan nilai akhir. Nilai akhir inilah sebagai indikator keberhasilan maha-siswa. Setelah dianalisis, maka hasil belajar maha-siswa semester VI kelas VI.E yang mempunyai kategori Sangat Baik sebanyak 54,04 \%; kategori Baik sebanyak 27,03 \%; dan kategori cukup sebanyak 18,92 \%. Pada uji coba prototype IV ini tidak terdapat mahasiswa yang hasil belajarnya tergolong dalam kategori Cukup dan kategori Gagal.

Jika persentase mahasiswa dilihat dari ketunta-san hasil belajar yang ditetapkan sebesar $75 \%$, maka $67,57 \%$ mahasiswa tuntas dalam memahami bahan ajar struktur aljabar berbasis website.

\section{Pembahasan}

Penelitian ini menghasilkan bahan ajar struktur aljabar berbasis website untuk pembelajaran struktur aljabar yang telah dikembangkan. Pada tahap pengembangan bahan ajar struktur aljabar berbasis website, peneliti pertama-tama mendesain materi bahan ajar berbasis paper based terlebih dahulu, setelah uji validasi isi bahan ajar oleh pakar, kemudian dilanjut-kan dengan mendesain materi bahan ajar berbasis computer based.

Tahap pengembangan bahan ajar struktur alja-bar berbasis website, peneliti merancangnya mengguna-kan software PHP + MySql dan Macromedia Flash 8.0 yang selanjutnya diedit menggunakan Macromedia Dreamweaver 8.0. Sofware PHP + MySql digunakan untuk mendesain materi agar bersifat personal dan sebagai database untuk menu yang membutuhkan penyimpanan data. Sedangkan Macromedia Flash 8.0 digunakan untuk mendesain latihan soal dan evaluasi. Hasil desain materi tersebut kemudian di-upload ke web hosting http://tesisku.uuuq.com di mana layout tampilan web memanfaatkan hosting gratis yang mendukung PHP + MySql yang ada pada hosting tersebut. Untuk meningkatkan performa website, peneliti memanfaatkan fasilitas dari forum untuk hyperlink tanya jawab mengenai materi.

Berdasarkan hasil analisis data prototype I masih ada kekurangan mengenai isi materi, perbaikan dilakukan berdasarkan saran pakar. Pada prototype I pengembangan bahan ajar struktur aljabar masih berbentuk paper based. Revisi prototype I sebagai dasar untuk mendesain bahan ajar dalam bentuk computer based (website), hasil dari revisi prototype I menghasilkan prototype II.

Berdasarkan hasil analisis data prototype II masih banyak kekurangan baik mengenai materi, tampilan latihan soal dan evaluasi pada flashnya, maupun dalam hyperlink halaman pada website. Hal ini menunjukkan bahwa prototype II belum efektif jika dipelajari oleh mahasiswa. Selanjutnya, revisi 
prototype II menghasilkan prototype III yang kemudian dilakukan uji validitas dan uji coba ke responden penelitian kelompok kecil (5 orang mahasiswa semester VI kelas VI.I). Uji validitas terhadap pakar menunjukkan bahwa penyajian materi pada prototype III telah lebih baik dari prototype II, tetapi masih belum adanya menu untuk logout untuk mengganti user dan belum jelas karakter maksimum nama pengguna. Ini menunjukkan prototype III masih belum efektif dan perlu dilakukan revisi kembali.

Revisi prototype III menghasilkan prototype IV di mana saran-saran dari pakar dan kejadian di lapangan saat uji coba prototype III dijadikan sebagai acuan. Berdasarkan hasil analisis data menunjukkan bahwa prototype IV lebih baik dari prototype III. Hal ini dapat dilihat dari hasil observasi tingkat motivasi mahasiswa semester VI kelas VI.E dalam belajar man-diri tidak ada lagi mahasiswa yang masuk dalam kategori Kurang Termotivasi pada pertemuan kedua. Dari angket motivasi, ketika mahasiswa tidak mema-hami materi yang ada pada website, maka tidak ada lagi mahasiswa yang melewatinya, dan sebagian besar berusaha memahaminya sendiri dengan mengulangi lagi. Ketika mahasiswa mengerjakan latihan pada website, maka hanya 29,73\% langsung mengklik atau menginput nilainya hanya dengan memperkirakan saja, dan ketika mahasiswa mendapatkan nilai < 75 setelah mengerjakan latihan pada website, maka hanya 5,41\% tidak mengulanginya lagi.

Dari sikap mahasiswa, hanya 2,70\% mahasiswa yang kurang tertarik belajar mandiri menggunakan website. Jika dilihat dari hasil belajar, tidak ada mahasiswa yang masuk dalam kategori kurang dan gagal, dan ketuntasan belajar secara klasikal mencapai $67,57 \%$. Ini menunjukkan prototype IV telah potensial efektif dalam memotivasi, memperbaiki sikap siswa, dan meningkatkan hasil belajar. Oleh karena itu, prototype IV dianggap sebagai hasil akhir dari desain bahan ajar struktur aljabar berbasis website pada materi sifat-sifat grup, subgrup, dan order grup yang telah sesuai dengan klasifikasi karakteristik pembelajaran yang menggunakan media komputer menurut Roblyer (dalam Said, 2004), yaitu.

1. Telah tercapainya kompetensi dasar dengan 54,05\% mahasiswa masuk dalam kategori Sangat Baik; 27,03\% mahasiswa masuk dalam kategori Baik; dan 18,92 \% mahasiswa masuk dalam kategori cukup.

2. Telah sesuai dengan karakteristik mahasiswa Prog-ram Studi Pendidikan Matematika FKIP Universi-tas PGRI Palembang yang memiliki literasi kompu-ter yang baik dengan tidak terdapatnya keluhan dalam mengoperasikan komputer.
3. Telah terjadinya interaksi antara mahasiswa dengan komputer, mahasiswa dengan mahasiswa, mahasiswa dengan dosen, dengan memanfaatkan fasilitas komunikasi berupa forum pada website.

4. Telah terciptanya suasana belajar mandiri dengan turunnya 21,62\% deskriptor mahasiswa yang bertanya bila memerlukan pada pertemuan kedua.

5. Telah mempertahankan minat mahasiswa dengan naiknya $8,11 \%$ deskriptor berkonsentrasi pada pertemuan kedua.

6. Telah memberikan sikap yang positif kepada mahasiswa dengan naiknya 48,65\% deskriptor mengekspresikan perasaan gembira pada pertemu-an kedua.

7. Telah efektif dalam memberikan umpan balik dengan munculnya skor setelah menyelesaikan latihan maupun evaluasi secara interaktif.

8. Telah sesuai dengan lingkungan pembelajaran yang setiap satu komputer dihadapkan pada satu orang mahasiswa.

9. Telah dirancang berdasarkan prinsip desain pem-belajaran dengan dimulainya tutorial materi dan diakhiri dengan pemberian latihan interaktif pada akhir materi.

10. Telah dievaluasi melalui uji validitas terhadap enam pakar dan uji coba ke lapangan dengan lima responden dari mahasiswa semester VI kelas VI.I (kelompok kecil) dan 37 responden dari mahasiswa semester VI kelas VI.E (kelompok eksperimen).

Hasil penelitian ini juga memiliki beberapa kekurangan baik secara isi materi maupun teknisnya, sehingga diharapkan pengembangan bahan ajar struktur aljabar berbasis website selanjutnya dapat menggunakannya sebagai acuan. Berikut kekurangan-kekurangan tersebut.

1. Bahan ajar struktur aljabar berbasis website yang dikembangkan hanya terbatas pada materi sifat-sifat grup serta subgrup dan order grup.

2. Karena keterbatasan peneliti dalam pembuatan program, maka materi pada soal latihan hanya pada materi yang bisa dikomputerisasikan saja.

3. Selain itu, karena latihan soal dan evaluasi menggu-nakan flash, skor akhir belum ada database-nya.

4. Materi dan latihan/evaluasi terpisah tidak dalam satu objek, materi menggunakan html dan latihan/ evaluasi menggunakan flash.

5. Materi dan latihan/evaluasi masih bersifat statik, untuk mengubah/mengedit harus membuka html nya, ini dikarenakan simbol-simbol matematika kadang-kadang tidak terbaca oleh website.

6. Belum adanya suara yang mendukung tutorial materi. 

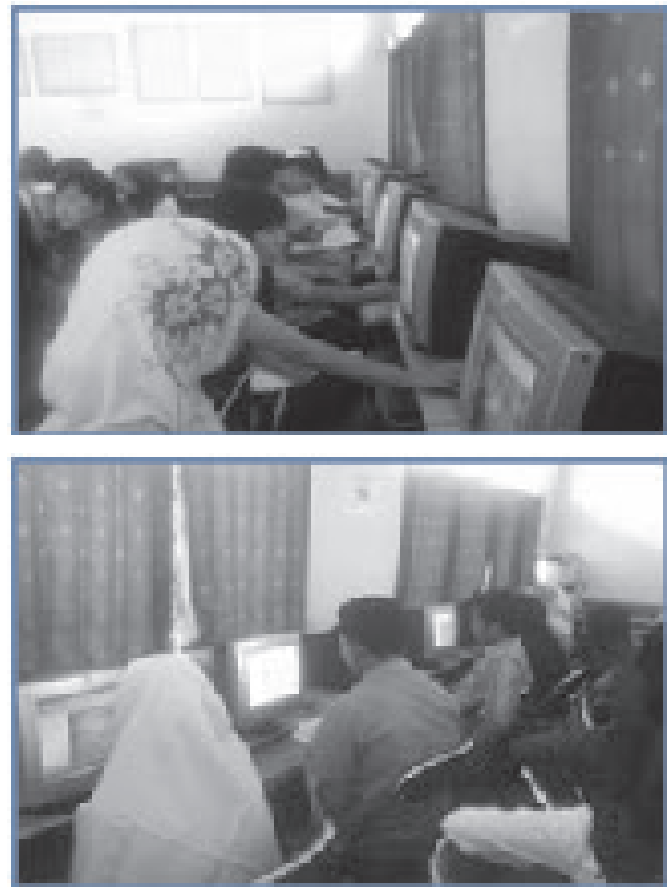

Gambar 5. Mahasiswa Sedang Belajar Mandiri Menggunakan

Bahan Ajar Struktur Aljabar Berbasis Website

Dengan demikian, bahan ajar struktur aljabar berbasis website yang telah dikembangkan peneliti valid dan praktis ketika digunakan dalam kegiatan pembe-lajaran pada mahasiswa semester VI kelas VI.E Pro-gram Pendidikan Matematika FKIP Universitas PGRI Palembang. Hal ini dapat dilihat dari tingkat motivasi mahasiswa, sikap mahasiswa, dan hasil belajar mahasiswa yang tergolong dalam kategori baik, artinya bahan ajar struktur aljabar berbasis website dapat dijadikan alternatif dalam pembelajaran struktur aljabar.

\section{PENUTUP}

\section{Kesimpulan}

Berdasarkan hasil penelitian, maka dapat disimpulkan berdasarkan proses pengembangan diperoleh bahwa prototype IV yang telah dikembang-kan peneliti valid dan praktis ketika digunakan dalam kegiatan pembelajaran pada mahasiswa semester VI kelas VI.E Program Pendidikan Matematika FKIP Universitas PGRI Palembang dengam tingkat motivasi mahasiswa termasuk dalam kategori "termotivasi", sikap mahasiswa termasuk dalam kriteria "tertarik", dan hasil belajar mahasiswa termasuk dalam kategori rata-rata "sangat baik".

\section{Saran}

Berdasarkan hasil penelitian dan kesimpulan tersebut, maka dapat disarankan sebagai berikut, dosen bidang program studi pendidikan matematika, agar dapat menggunakan bahan ajar berbasis website sebagai alternatif pembelajaran; mahasiswa, agar mengakses bahan ajar berbasis website baik di kampus maupun di luar kampus sehingga menambah pemaha-man mengenai materi yang sedang dipelajari maupun meningkatkan literasi komputernya; dan IPTEK, diharapkan dapat mengembangkan suatu software yang dapat mempermudah dosen maupun peneliti lain dalam mendesain materi ajarnya sendiri.

\section{DAFTAR PUSTAKA}

Akker, J.V. (1999). Design approaches and tools in education and training. Dordrecht: Kluwer Academic Publishers.

Fauzan, A. (2002). Applying realistic mathematics educa-tion (RME) in Teaching Geometry in Indonesian Primary Schools. Tesis Twente University Ensche-de. Tidak dipublikasikan.

Hartanto, A.A. \& Purbo, O.W. (2002). Teknologi e-learning berbasis PHP dan MySql. Jakarta: Elex Media Komputindo.

Miarso, Y. (2007). Menyemai teknologi pendidikan. Jakarta: Kencana Prenada Media Group.

Wahono, R.S. (2006). Aspek dan kriteria penilaian media pembelajaran. Diakses pada tanggal 18 November 2007 dari http:// romisatriawahono. net/2006/06/21/aspek-dan-kriteria-penilaian-media-pembelajaran/

Wahono, R.S. (2007). Pengantar media pembelajaran. Diakses pada tanggal 18 November 2007 dari http://mustolihbrs.wordpress.com/ 2007/09/11/pengantarmedia-pembelajaran/)

\section{KETERANGAN PENULIS}

Fadli, lahir di Palembang pada tanggal 11 September 1976. Saat ini aktif menjabat sebagai Dosen Kopertis wilayah 2 Depok pada STKIP PGRI Lubuklinggau. 